\title{
Cold seep benthic communities in Japan subduction zones: spatial organization, trophic strategies and evidence for temporal evolution*
}

\author{
S. Kim Juniper**, Myriam Sibuet \\ IFREMER, Centre de Brest, BP 337, F-29273 Brest Cedex, France
}

\begin{abstract}
Submersible exploration of the Japan subduction zones has revealed benthic communities dominated by clams (Calyptogena spp.) around sediment porewater seeps at depths from 3850 to $6000 \mathrm{~m}$. Photographic and video records were used to produce microcartographic reconstructions of 3 contrasting cold seep sites. Spatial and abundance relations of megafauna lead us to propose several hypotheses regarding the ecological functioning of these cold seep communities. We distinguish between the likely direct use of reducing substances in venting fluids by Calyptogena-bacteria symbioses and indirect usage by accompanying abyssal species not known to harbour symbionts. Microdistribution and known or presumed feeding modes of the accompanying species indicate 2 different sources of organic matter enrichment within cold seep sites: organic debris originating from bivalve colonies, and enrichment of extensive areas of surrounding surface sediments where weaker, more diffuse porewater seepage may support chemosynthetic production by free-living bacteria. The occurrence of colony-like groupings of empty Calyptogena valves indicates that cold seeps are ephemeral, with groups of living clams, mixed living and dead clams, and empty dissolving shells marking the course of a cycle of porewater venting and offering clues to the recent history of cold seep activity
\end{abstract}

\section{INTRODUCTION}

The discovery of deep-sea hydrothermal vents has recently been followed by the finding of several other forms of seafloor emissions of dissolved reducing substances which fuel chemosynthesis-based benthic communities. Presently the latter appear to be of 3 major types: brine seeps, oil/gas seeps and subduction zone cold seeps. Deep-sea brine seeps are now known from a site $(3270 \mathrm{~m})$ near the base of the tectonically inactive Florida escarpment (USA). Unlike shallow-water brine seeps (Powell et al. 1986) these seeps of sulfide-rich hypersaline fluid were found to support a fauna remarkably similar to that at hydrothermal vents in the East Pacific Ocean (Hecker 1985). A taxonomically different fauna of bivalves and Vestimentifera (Lamellibranchia) has been dredged from $500 \mathrm{~m}$ deep oil and gas seeps on the Louisiana slope (Kennicutt et

\footnotetext{
- Contribution No. 94 from IFREMER, Centre de Brest

- Present address: Department of Biology, University of Victoria, Victoria, British Columbia V8W 2Y2, Canada
}

al. 1985). One of the bivalve species from this area has been shown to harbour symbiotic bacteria in its gill tissue and to oxidise methane (Childress et al. 1986), confirming that methane, as well as hydrogen sulfide, can serve as energy source for invertebrate/bacteria symbioses. Subduction zone cold seeps occur at tectonically active continental margins. Kulm et al. (1986) made the first discovery of this phenomenon on the Oregon continent margin, finding aggregations of clams and Vestimentifera associated with seeps of methane-rich fluids. They proposed that the fluids originated as deep sediment porewaters that migrated to the seafloor surface along fault planes during the subduction process, possibly as a result of compression of subducting sediments. Dissolved methane appears to be the energy source for these cold seep communities (Kulm et al. 1986).

A recent Franco-Japanese submersible expedition to the subduction zones in the Japan region (Kaiko program) revealed biological exploitation of sediment porewater seeps at depths from 3850 to near $6000 \mathrm{~m}$ (Bolègue et al. 1985, Cadet et al. 1985, Swinbanks 
1985a, b, Laubier et al. 1986, Le Pichon et al. 1987, Ohta \& Laubier 1987). These cold seep communities are characterised by the dominance of several species of the vesicomyid clam Calyptogena, the absence of Vestimentifera and a remarkable local enrichment of abyssal benthic organisms (Laubier et al. 1986, Ohta \& Laubier unpubl.).

Apart from the role of chemosynthesis, little is known of the ecological functioning of 'seep' communities. Their discovery is very recent, only a handful of sites have been described, and researchers have tended to be first concerned with taxonomic and physiological problems. In addition to symbiotic bivalves and Vestimentifera, many other organisms representing a variety of feeding modes are clearly associated with active seeps: scavenging and predatory fish and crustaceans, deposit-feeding gastropods and holothurians, suspension-feeding polychaetes and anemones. The presence of these other organisms, as well as the variable presence of bivalves and Vestimentifera, invokes questions regarding food web structure, faunal habitat requirements, interspecific interactions, etc. The more than 50 cold seep sites documented during the course of the 1985 Kailko diving program have presented an opportunity to observe trends in community development and organisation and to study them in detail. Analysis of this component of the deep sea benthos is necessarily selective. Cold seeps are very small in area and often separated by hundreds or even thousands of metres. Traditional random sampling techniques are thus an inefficient means of data gathering, and sites must be located and selectively sampled by submersible. In this paper we examine the structural and spatial organization of the megafauna at 3 heavily colonised sites discovered in the Japan Trench and the Nankai Trough. The communities of clams Calyptogena and their accompanying fauna were studied from microcartographic reconstruction of each site. Our goal was to use observed microdistribution as a guide to develop a preliminary picture of the exploitation of cold seeps by various trophic groups. This approach, similar to that used by Fustec et al. (1987) at hydrothermal vents, has also revealed distinct patterns of community structure and demography, the latter leading us to consider possible patterns of temporal evolution of the biocoenoses following initial colonisation by Calyptogena. Another paper (Sibuet et al. unpubl.) examines patterns of cold seep community development in relation to substratum, faulting and other geological features of the subduction zone environment.

\section{ANALYTICAL METHODS}

Video and photographic documentation. An external color video camera and internal VCR on the sub- mersible Nautile provided a continuous video log of all dives. Time, depth and submersible heading were overwritten on the video image, allowing observations to be located on the submersible's dive track. An externally-mounted $35 \mathrm{~mm}$ camera (BENTHOS Model 372) and strobe, activated from within the submersible, provided an oblique monocular photographic record. A data chamber in the camera added depth and time data, allowing video and photographic information to be matched.

Examination of video and photo-documentation. All video and photo-documentation from the 10 dives reporting the presence of clam colonies were examined. In addition, photo records from several dives not reporting clam colonies were examined, as a reference to the general character of the abyssal fauna in the explored region. Visual information was used to assemble an inventory of all observed clam colonies, and to identify qualitative differences between fauna accompanying the clams and the surrounding abyssal fauna. This information is reported in another paper (Sibuet et al. unpubl.). Three of the most welldeveloped and most differing sites were then selected for detailed analysis of faunal microdistribution.

Microcartography. Metre-scale maps of each selected site were drawn, in overlay, from photomosaics to reconstruct the location of individual organisms, the living/dead condition of visible clams and the major physical features of the habitat. Living clams were identified in the photographs from their upright posture and visible mantle tissue, and dead clams by their open valves in various states of dissolution. Scale in the photo-mosaics was extrapolated from the size of clam shells lying horizontally, using size data of clams taken in samples. Since viewing angle and camera-tosubject distances were not measurable in the photos, scale estimations were only approximate. This, however, did not detract from the primary purpose of the maps which was to reveal relative spatial organisation of the fauna.

\section{RESULTS}

Sites selected for microcartographic analysis (Fig. 1) are located in Tenryu Canyon in the Nankai Trough (Dives 26 \& $28 ; 33^{\circ} 37^{\prime} \mathrm{N}, 137^{\circ} 32^{\prime} \mathrm{E} ; 3830 \mathrm{~m}$ depth), in the Japan Trench at Kashima Seamount (Dive 43; $35^{\circ} 54^{\prime} \mathrm{N}, 142^{\circ} 31^{\prime} \mathrm{E} ; 5640 \mathrm{~m}$ depth) and at another site in the Japan Trench (Dive 48; 40 06' $\mathrm{N}, 144^{\circ} 10^{\prime} \mathrm{E}$; $5900 \mathrm{~m}$ depth). Geological description and location of these sites in relation to local bathymetry are given by Sibuet et al. (unpubl.). Substrata at these sites were soft sediment (Tenryu Canyon and Kashima Seamount) or mudstone (Japan Trench Dive 48). 


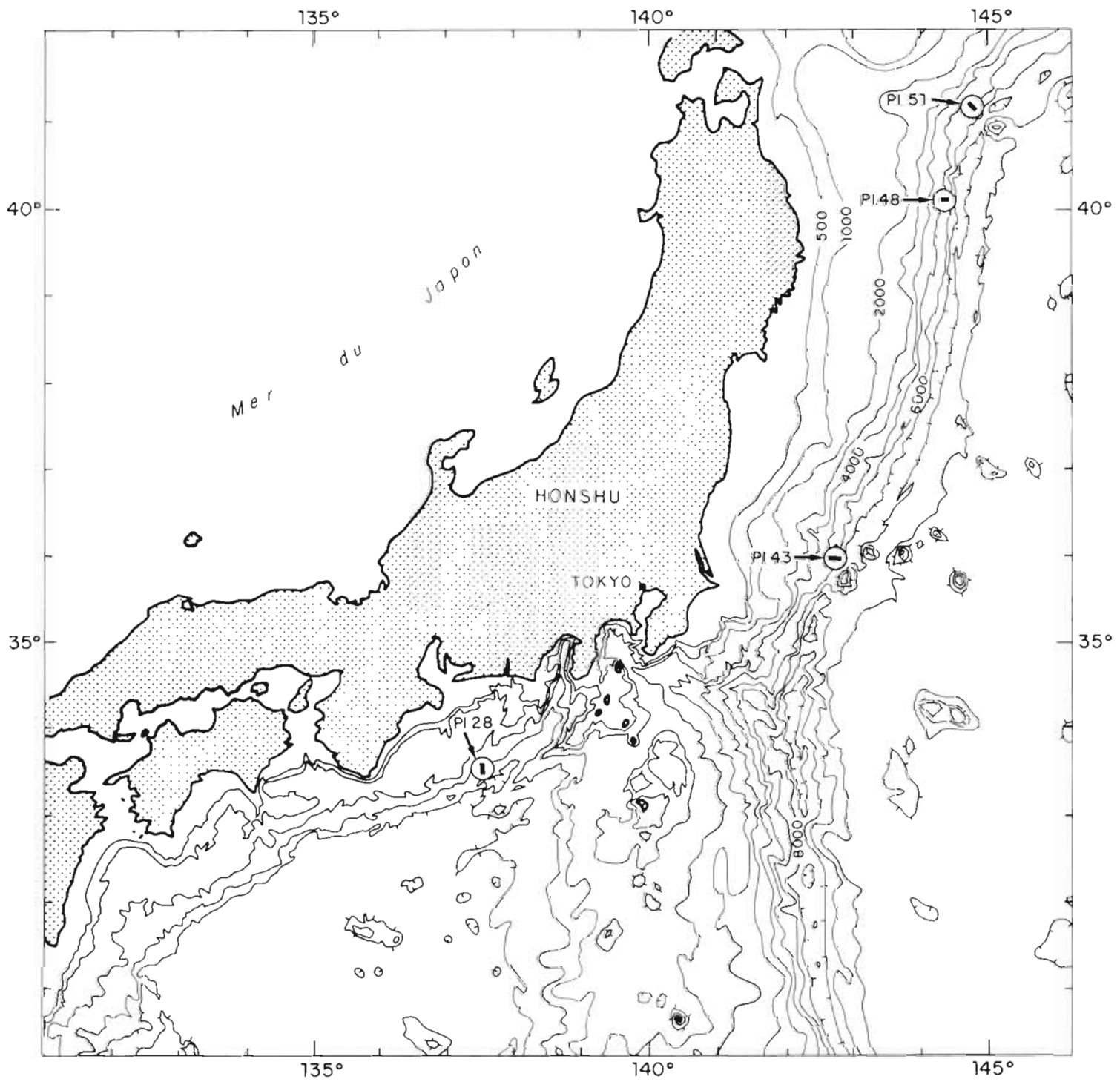

Fig. 1. Bathymetry of the Pacific Ocean in Japan Region showing subduction zones and selected dive sites. Dive 28 (Pl. 28) was located in Tenryu Canyon near its intersection with the Nankai Trough, the subduction zone off southeastern Japan. Dive 43 (Pl. 43) was made at the site of subduction of Kashima Seamount in the Japan Trench. Dive 48 (Pl. 48) explored the inner wall of the Japan Trench upward from near $6000 \mathrm{~m}$. See Sibuet et al. (unpubl) for detailed description of these sites

\section{Tenryu Canyon}

Several fields of Calyptogena colonies were aligned along thrust faults on the wall of Tenryu Canyon. This is a flat-floored canyon which transects the accretionary prism forming on the landward wall of the Nankai Trough (Fig. 1) (Sibuet et al. unpubl.). A $1 \times 4 \mathrm{~m}$ section of the largest observed alignment of clam colonies $(10 \times 2 \mathrm{~m})$ was reconstructed from a photomosaic (Fig. 2). Limited photographic coverage did not permit analysis of the entire site. Two groups of clams can be distinguished in this section. In the upper left of Fig. 3 is a tightly-aggregated colony of 60 -mostly live - clams, partially buried in the sediment (Fig. 3A).
Three species, Calyptogena (Ectenagena) nautilei n. sp., C. (Ectenagena) laubieri n. sp. and C. (Ectenagena) kaikoi n. sp. have been identified from samples taken at this site (Okutani \& Métivier 1986), and a box core taken in the above group contained 2 species. Shell lengths ranged from 114 to $129 \mathrm{~mm}$ for $C$. nautilei, 39 to $74 \mathrm{~mm}$ for C. laubieri and 46 to $82 \mathrm{~mm}$ for C. kaikoi (Okutani \& Métivier 1986). The second more widely spaced colony, in the lower right, was dominated by dead but articulated clams (Fig. 3B). Between the 2 clam colonies were a few scattered living and dead clams. Distinct spatial separation of colonies of living and dead clams also occurred on a larger scale at this site, with one region of the $10 \times 2 \mathrm{~m}$ field of clam 


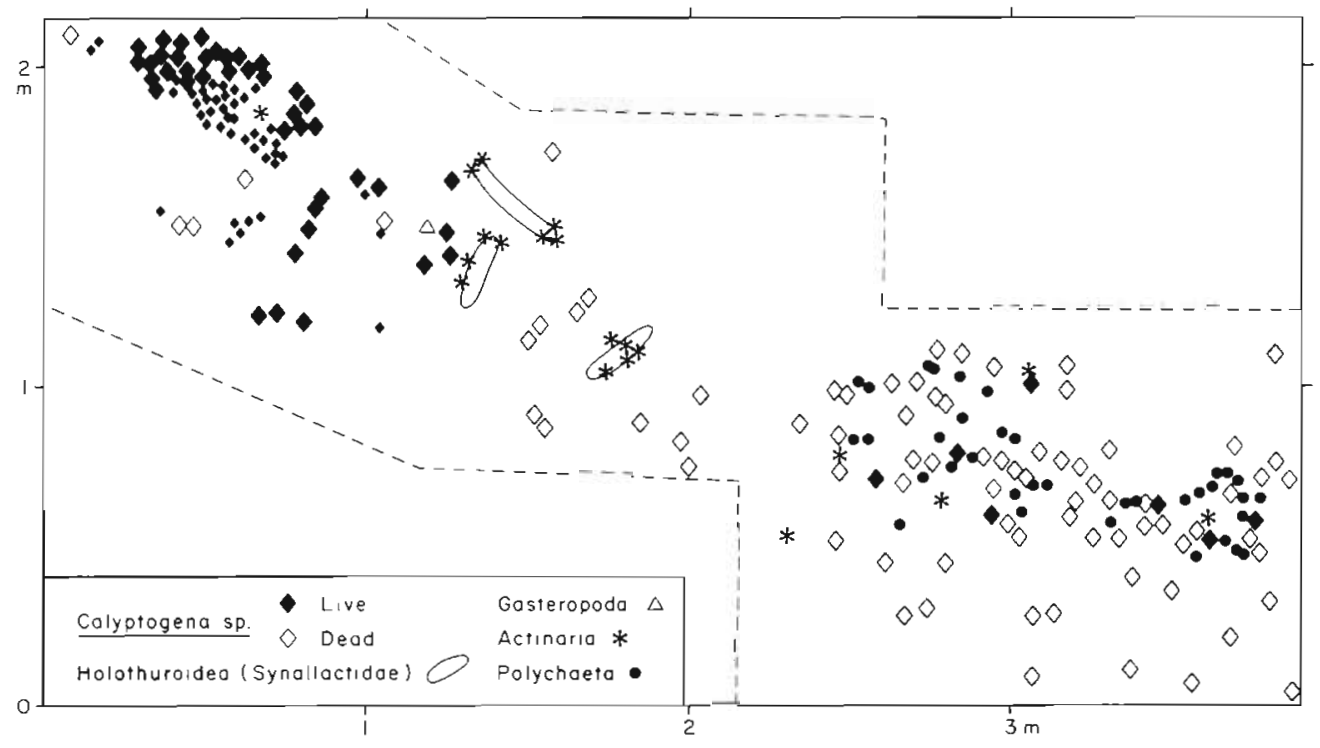

Fig. 2. Microcartographic reconstruction of the area partially shown in Fig. 3. Zone outside dashed lines not covered by photo mosaic but video records indicate that alignment of depicted colonies is representative of the orientation of the larger clam field from which this section was extracted. Smaller clam symbols represent small-sized individuals. The area shown represents a zone of transition from an area of living clam colonies to an area dominated by dead clams. Substratum is a thick sediment cover

colonies being dominated by living clams and the other by dead clams. The selected section represents the zone of transition from the region of living to dead colonies.

The most abundant accompanying species at this site were mainly suspension feeders. Numerous serpulid polychaetes were attached to empty clam valves in the second colony (Fig, 2, see also Fig. 3B). No serpulids were associated with the colony dominated by living clams, although some were attached to surfaces of nearby rocks and boulders. Actinarians of several species occurred on a variety of surfaces: living and dead clam shells, boulders and the surface of holothurians. Suspended organic particle concentrations at this site appear favorable to suspension feeders, and these organisms may be limited by the availability of hard substrata. A large holothurian (family Synallactidae) was the only detritivore at this site. Its distribution was rather uneven, and fewer than 5 individuals were present within the $10 \times 2 \mathrm{~m}$ field of clam colonies. Two mobile scavenger/carnivore species, a gastropod and a galatheid crab, were present at this site at densities of 1 to 2 individuals per clam colony. However, comments by the scientific observer of Dive 28 suggested that galatheid crabs were more numerous than indicated by video and photo-documents. There was a remarkable density of grooved tracks on the sediment surface at this and other clam sites in the area, suggesting considerable locomotory activity by some species. Scientific observers on the 2 dives at this site report seeing gastropods and an individual clam moving over the sediment surface and leaving groove-like tracks. Major features of this and the following 2 sites are summarised in Table 1.

\section{Kashima Seamount}

A single colony of more than 100 living and dead clams belonging to a fourth Calyptogena species, $\mathrm{C}$. (Ectenagena) phaseoliformis n. sp., (Métivier et al. 1986) was located in a small gully on a steep slope of the inner wall of the Japan Trench at the site of subduction of Kashima Seamount (Fig. 1). The colony was aligned along a sediment slide scar. The upslope portion consisted of nearly 50 living clams which were closely grouped within the fracture (Fig. 4 A). A similar number of dead clams comprised the lower portion of the colony, and numerous disarticulated empty shells were scattered along a line further down the slope, apparently transported by visible slumping of sediment (Fig. 5).

Abundant swimming holothurians Peniagone elongata were concentrated on the sediment surface near the clams. Nearly 60 individuals were counted in the area depicted in Fig. 5 (ca $5 \mathrm{~m}^{2}$ ). Many swimming individuals were also visible in the video and photo records during the passage through the area of the slope where this and several non-living clam colonies were found. Tube-dwelling polychaetes (Ohta \& 


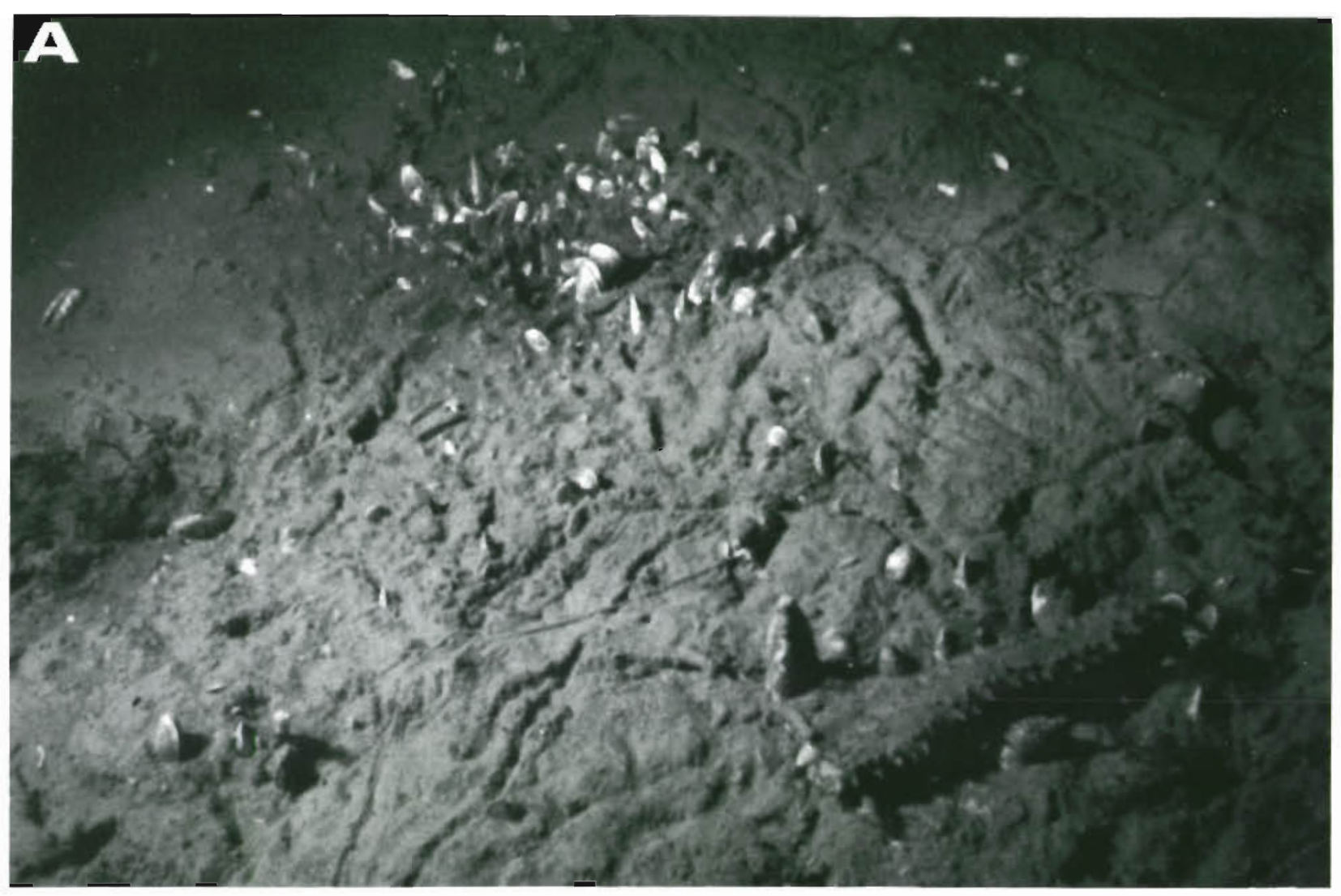

\section{$\mathbf{B}$}

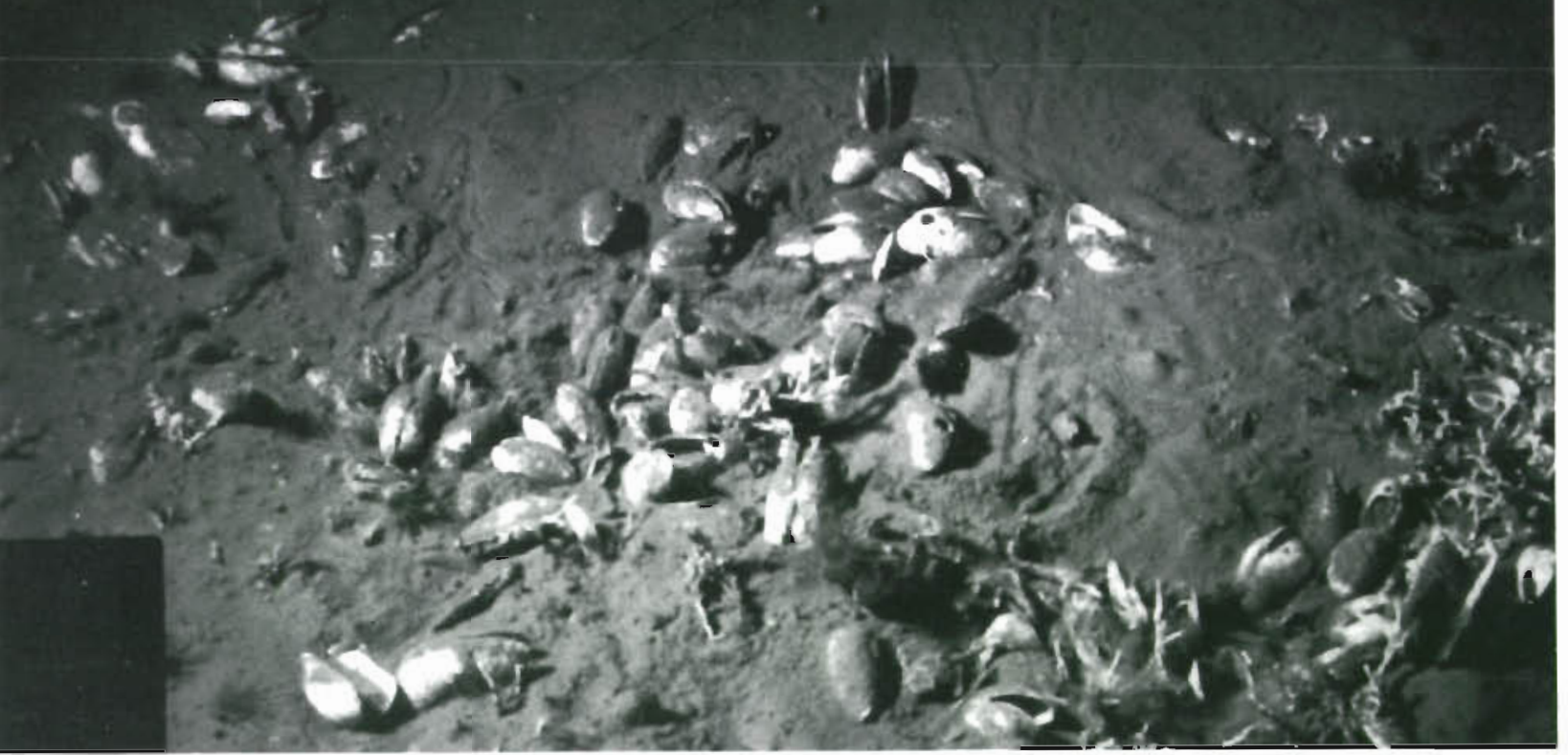

Fig. 3. Photographs of portions of the studied section of the large Tenryu Canyon Calyptogena field. (A) Colony dominated by Living clams, with a large holothurian and few other living clams located nearby. (B) Colony of mainly dead clams with serpulid polychaetes and occasional actinarians attached to empty clam shells; a small galatheid crab is visible on the left 
Table 1 Summary of major features of reconstructed cold seep faunal communities from sites in the Japan subduction zones

\begin{tabular}{|c|c|c|}
\hline Site & Calyptogena colonies & Accompanying tauna \\
\hline $\begin{array}{l}\text { Tenryu Canyon } \\
\text { (Dive } 28 \text { ) }\end{array}$ & $\begin{array}{l}\text { - Distinct colonies of mainly living clams or ar- } \\
\text { ticulated empty valves; clams partially buried } \\
\text { in sediments } \\
\text { - C. nautilei, C. Iaubieri and C. kaikoi } \\
\text { - Colony size: } 60 \text { to } 70 \text { clams }\end{array}$ & $\begin{array}{l}\text { - Serpulids and actinarians on dead clams and } \\
\text { other hard surfaces } \\
\text { - Small numbers of galatheids, large holothu- } \\
\text { rians and gastropods on sediment surround } \\
\text { clams }\end{array}$ \\
\hline $\begin{array}{l}\text { Kashima Seamount } \\
\text { (Dive } 43 \text { ) }\end{array}$ & $\begin{array}{l}\text { - Single mixed colony of living clams and articu- } \\
\text { lated empty valves; clams partially buried in } \\
\text { sediment } \\
\text { - C. phaseoliformis only } \\
\text { - Colony size: }>100 \text { clams }\end{array}$ & $\begin{array}{l}\text { - Abundant caprellid amphipods in and around } \\
\text { clam colony } \\
\text { - Abundant Peniagone and tubiculous } \\
\text { polychaete on sediments around clam colony } \\
\text { - Single actinarian on clam shell }<5 \text { gastropods } \\
\text { - Visit by } 2 \text { fish after release of clam blood }\end{array}$ \\
\hline $\begin{array}{l}\text { Japan Trench } \\
\text { (Dive } 48 \text { ) }\end{array}$ & $\begin{array}{l}\text { - Distinct colonies of mainly living clams or ar- } \\
\text { ticulated empty valves; clams epibenthic on } \\
\text { mudstone } \\
\text { - C. phaseoliformis only } \\
\text { - Colony size: } 20 \text { to } 100 \text { clams }\end{array}$ & $\begin{array}{l}\text { - Abundant caprellid amphipods in and around } \\
\text { clam colonies } \\
\text { - Extensive area around colonies occupied by } \\
\text { tubiculous polychaetes implanted in mudstone } \\
\text { - } 5 \text { gastropods } \\
\text { - No Peniagone }\end{array}$ \\
\hline
\end{tabular}

Laubier 1987), likely detritivores, also surrounded the clam colony. In comparison to that of $P$. elongata, polychaete distribution was more restricted and in closer proximity to the clams (Fig. 5). Crustaceans identified as caprellid amphipods (not sampled) (Ohta \& Laubier 1987), up to $5 \mathrm{~cm}$ long, were very abundant at this site. They were most numerous within and near the clam colony, but they occurred as well on the surrounding sediment surface where they occupied approximately the same area as $P$. elongata (Fig. 5). Caprellids have seldom been observed in photographs or faunal samples from the deep-sea. In coastal waters, caprellids are omnivorous. The only known abyssal species, collected in the East Pacific Ocean at 3500 to $4000 \mathrm{~m}$, may have browsed upon the associated sessile fauna (McCain 1966). Only a single actinarian was present, attached to a clam shell. A few gastropods were visible within and near the clarn colony.

\section{Japan Trench}

The site reconstructed in Fig. 6 represents a portion of a field of more than 10 colonies of Calyptogena phaseoliformis n. sp. (Métivier et al. 1986) located on the slope of the inner wall of the Japan Trench between 5940 and $5900 \mathrm{~m}$ depth, in a subduction erosion setting (Fig. 1). The 3 colonies of clams in the illustrated section had rather different general features. The densely aggregated Colony A (Fig. 6, see also Fig. 4 B) consisted of ca 100 clams, nearly all living. Colonies B and $\mathrm{C}$ were much smaller: Colony $\mathrm{B}$ contained only living clams, numbering slightly less than 20, Colony $\mathrm{C}$ was a scattered assemblage of mainly dead clams occurring between boulders and rock outcrops. All living $C$. phaseoliformis at this site were epifaunal on the mudstone substratum. At the Kashima site this same species occurred partially-buried in soft sediment. A few empty clam shells were scattered throughout the site, but living clams occurred only within the 3 defined colonies. Tube-dwelling polychaetes, similar to those observed at the Kashima Seamount site, covered a very extensive area outside of the clam colonies. The polychaetes occupied a surface several times that covered by the 10 or more clam colonies found at this site. Approximately 250 polychaetes were visible within the area described by Fig. 6, corresponding to a density of near 100 ind $m^{-2}$. Polychaete tubes were vertically implanted in the mudstone substratum. These polychaetes were similarly abundant at several other sites in the Japan Trench. Caprellid amphipods were numerous throughout the site; they were visible resting on the substrata both within and outside the clam colonies (Fig. 6). Numerous actinarians were attached only to clam shells and not to adjacent rock surfaces although a single individual occurred on a gravel substrate near Colony A (Fig. 6). Five gastropods were counted within the analysed section. No swimming holothurians (Peniagone sp.) were seen.

\section{DISCUSSION}

\section{Direct utilisation of porewater: Calyptogena/bacteria symbiosis}

The clams are the only animals found at these sites for which there is evidence for direct utilisation of 


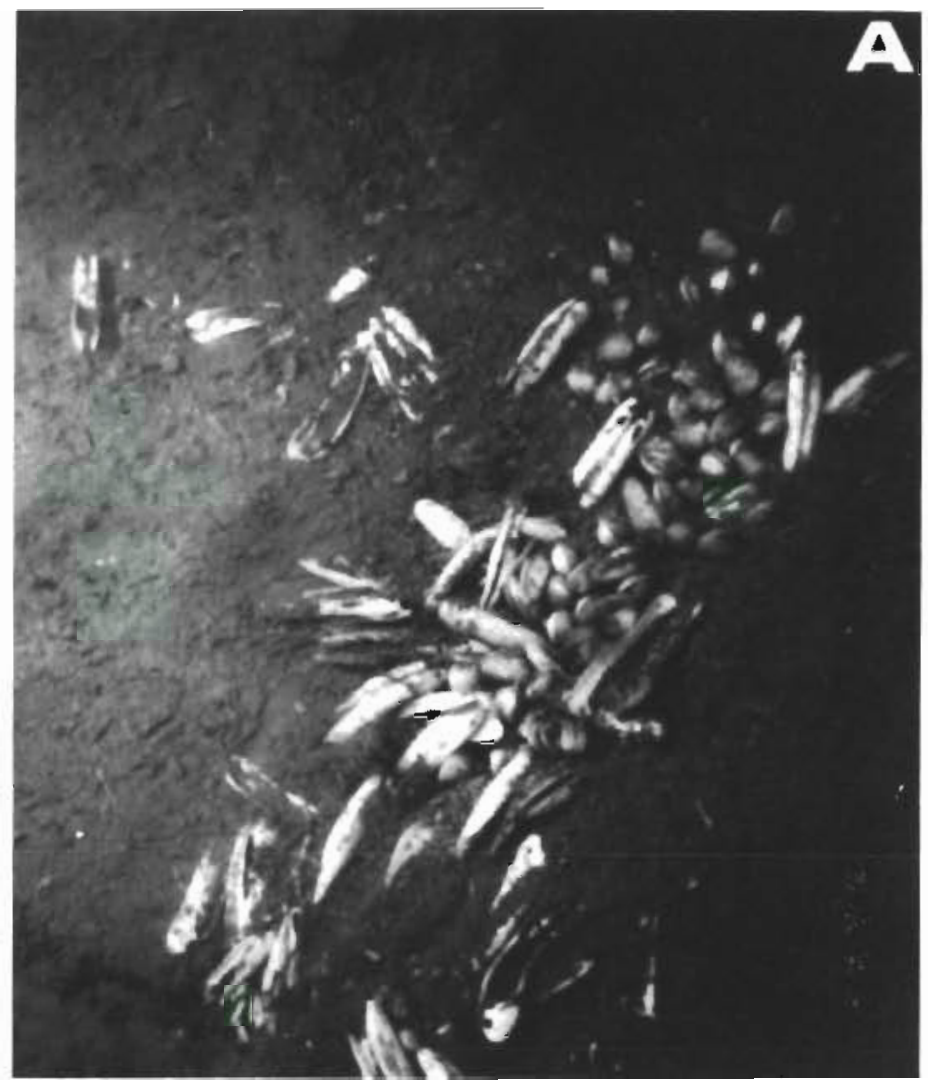

Fig. 4. (A) Large colony of living and dead clams at the Kashima Seamount site. Note aggregation of living clams in the upslope portion of the colony and the scattering of empty shells downslope. Accompanying species: polychaetes, swimming holothurians, caprellid amphipods and a gastropod. (B) Largest of the Calyptogena colonies (Colony A in Fig. 6) studied at the Japan Trench site (Dive 48). Note close aggregation of mainly living clams and the abundance of polychaete

tubes on the sediment surrounding the clams

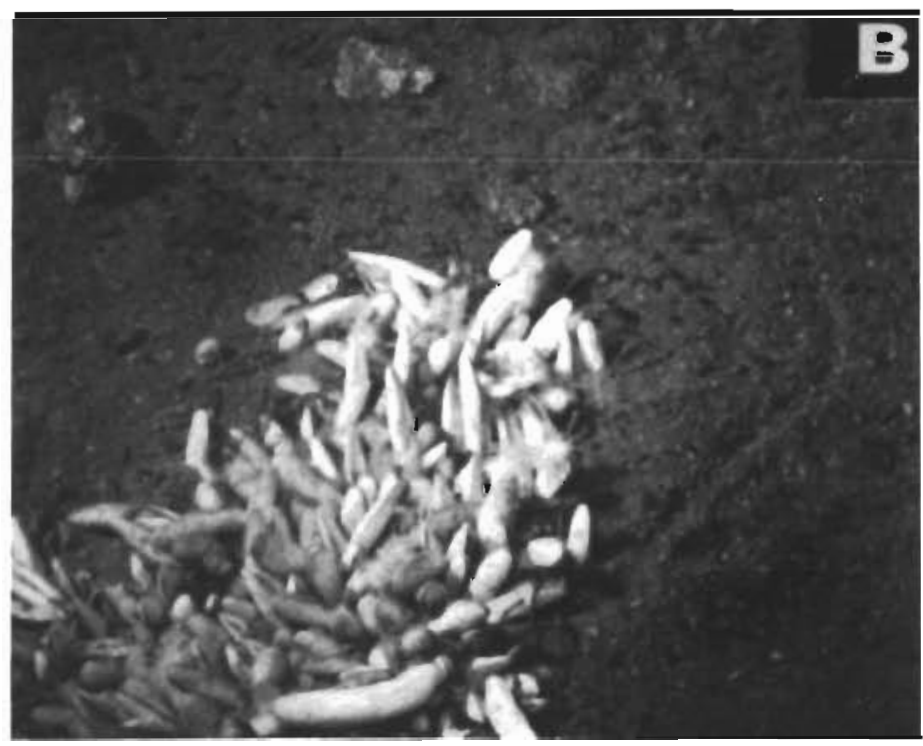

reducing substances in venting porewater via symbiosis with chemosynthetic bacteria. All 4 Kaïko species of Calyptogena are associated with sampled methane-rich cold seeps (Boulègue et al. 1987b). All 4 species have blood containing large amounts of haem proteins, suggesting an adaptation to the oxygen transport requirements of intracellar symbiosis (Ohta \& Laubier unpubl.j, Values of $\delta C^{13}$ in soft tissues of $C$. phaseoliformis (Boulègue et al. 1987a), are among the most negative reported for marine organisms ( -37.8 to -40.1 ).

Similar $\delta C^{13}$ values for the Oregon cold seep Calyptogena species have been interpreted to indicate that porewater methane, in addition to providing energy for symbiotic chemosynthesis, also serves as the clam's primary carbon source (Kulm et al. 1986). Ultrastructural analyses of gill tissue of C. phaseoliformis reveal endocellular bacteria (Boulègue et al. 1987a, A. Fiala 


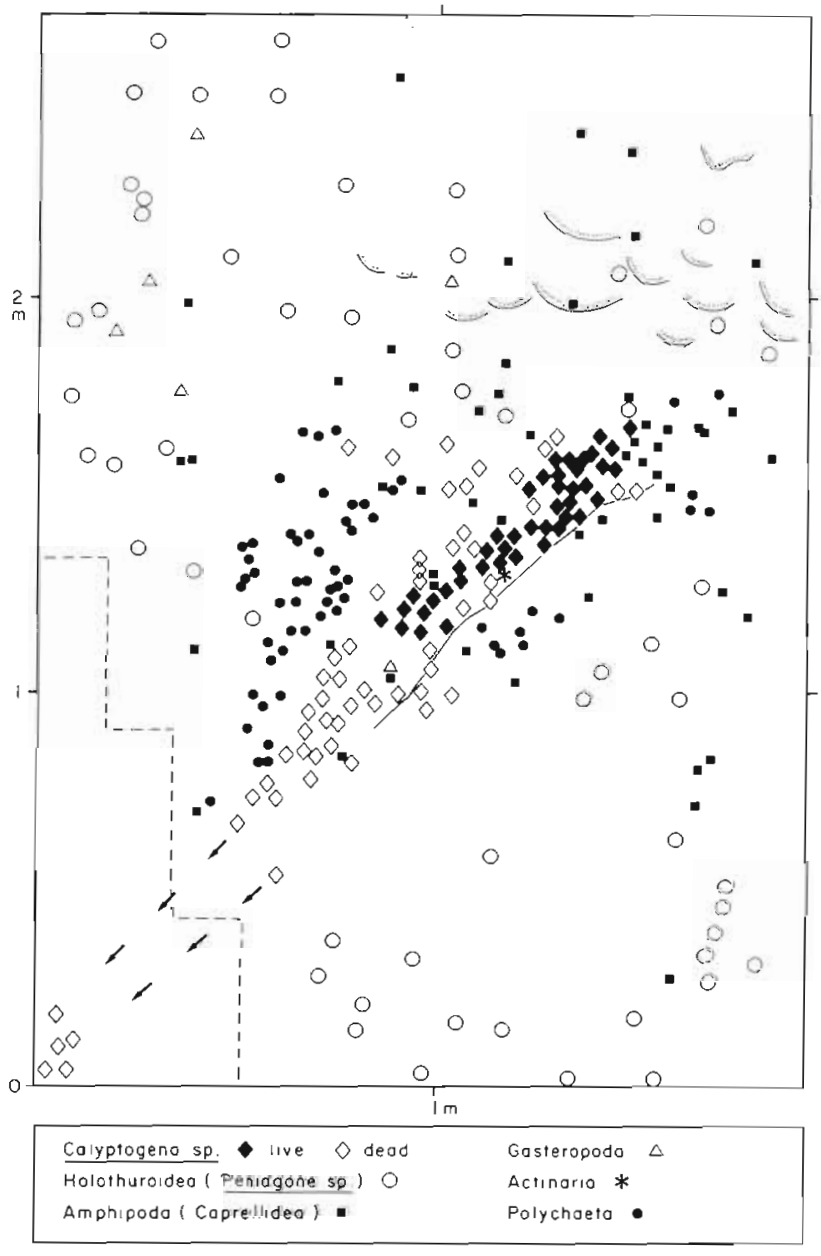

Fig. 5. Microcartographic reconstruction of cold seep community on a steep slope at the Kashima Seamount site. Diagonal line in centre marks position of the slump scar along which the clams were aligned. Arrows in lower left: downslope location of dead clam shells. Substratum is sediment with occasional exposure of underlying rock indicated by shaded areas

pers. comm.), which may be responsible for both oxidation of methane and incorporation of methane carbon into organic matter. Both of these processes have yet to be experimentally demonstrated for any species of Calyptogena. The presence of chemosynthetic activity in Calyptogena gill tissue is known from enzymatic studies of species found at hydrothermal vents (Felbeck et al. 1981, Cavanaugh 1983). Recent experiments with mussels from hydrocarbon seeps in the Gulf of Mexico have demonstrated, for the first time, the oxidation and incorporation of methane in bivalve gill tissue containing endocellular bacteria (Childress et al. 1986). Cavanaugh et al. (1987) also report the presence of endocellular bacteria with methyltroph-like ultrastructure in gill tissue of mussels from the Florida Escarpment brine seep sites. While a methane-based symbiosis seems very likely for these cold seep clams, a nutritional contribution from suspension feeding cannot yet be discounted. Kaiko Calyptogena species examined to date all have functional albeit extremely reduced digestive tracts containing particulate matter including phytoplankton debris ( $M$. Le Pennec pers. comm.). Clarification of the nutritional role of endosymbiotic bacteria in cold seep clams will require physiological experimentation. Symbiosis between invertebrates and chemosynthetic bacteria remains too poorly understood to permit firm conclusion from carbon isotope data and the presence of bacteria in gill tissue, particularly in animals anatomically capable of suspension feeding.

\section{Indirect utilisation of porewater: classic abyssal species}

Aggregation of omnivorous, deposit-feeding, and suspension-feeding species at these cold seeps suggests a local increase in food availability (Table 1). Biomass and organic debris produced by the clam colonies is one possible source of nutrition for some of the accompanying organisms. Organic matter is scarce at these depths and any significant local source of production is likely to be fully exploited by the abyssal fauna. Two fish quickly arrived at the Kashima site following sampling of clams and the release of clam blood. A similar observation was made at the Oregon cold seeps following sampling of clams (Kulm et al. 1986). While these fish may not be regular predators on the clams, they certainly appear capable of feeding on recently dead individuals. The abundance of colonylike groups of still-articulated valves seen at these and other sites suggests that clam colonies are rarely disturbed by large predators or scavengers (Rhoads et al. 1982, Hessler et al. 1985). The omnivorous galatheid crabs seen at the Tenryu Canyon site likely scavenge dead clams as well as deposit feeding on organic debris. Galatheids also aggregate around hydrothermal vent sites where their omnivorous habit, and possibly their tolerance of low oxygen conditions (Burd \& Brinkhurst 1984, Juniper \& Brinkhurst 1986), likely permit them to profit from the local production of biomass and organic debris. The few gastropods visible at all 3 sites are probably also omnivores attracted by the concentration of productivity at cold seeps.

The microdistribution of Peniagone and the tubedwelling polychaetes indicates that these organisms exploit surface sediments within an extensive zone surrounding the clam colonies (Table 1 ; Fig. $5 \& 6$ ). The input of sedimenting organic matter to these depths is very low, thus suggesting a dependence on the cold seeps. Additional organic debris from the clam colonies may still be insufficient to support such a high biomass. 
Fig. 6. Microcartographic reconstruction of a portion of a large clam field in the Japan Trench inner wall (Dive 48). Colonies A, B and C (see text) are indicated. Shaded areas: rock outcrops through the mudstone substratum

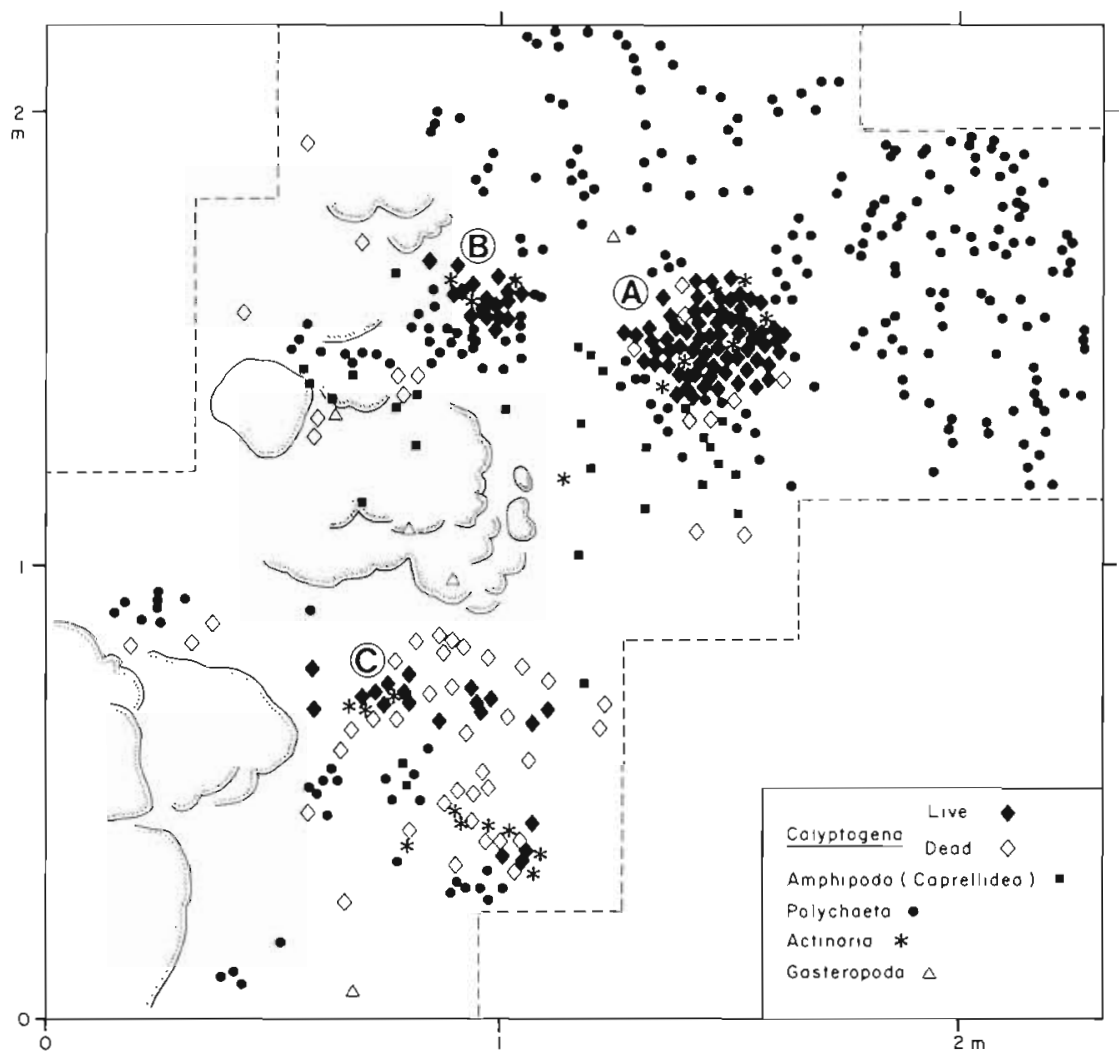

A supplementary food source may be localised in sediments peripheral to the clam colonies. One possibility is that diffuse porewater discharge, too weak to support clam colonies, supports bacterial productivity in surface sediments surrounding the clams, providing a local food enrichment for deposit feeders. The clam colonies would mark points of more intense fluid discharge, and colonisation of adjacent sediments by deposit feeders would indicate weaker, less localised venting that is utilisable by only free-living sediment bacteria. While sediment bacterial activity at cold seeps remains to be investigated directly, Kulm et al. (1986) report sediment porewaters from the Oregon cold seeps to be depleted in $\mathrm{NH}_{3}$ and total $\mathrm{CO}_{2}$. They interpret this as evidence of $\mathrm{CH}_{4}$ oxidation by sediment microorganisms. Aerobic bacterial oxidation of methane is well known from freshwater sediments (e.g. Rudd \& Hamilton 1975), and there is considerable geochemical evidence for anaerobic microbial methane oxidation in marine sediments (e.g. Devol 1983, Alperin \& Reeburgh 1985, Whiticar \& Faber 1986). There is yet no direct evidence for weaker porewater venting surrounding the clam colonies but dissipation of fluids escaping from underlying rock formations is likely as they pass upward through the sediment cover. Temperature measurements made at the Tenryu Canyon site reveal clear thermal anomalies above the centre of the clam colonies and occasional weaker anomalies in adjacent bottom waters (Boulègue et al. in press $b$ ).

Deposit feeding is the most likely mode of nutrition for these unsampled tube-dwelling polychaetes and holothurians. A priori no other trophic strategy appears possible for Peniagone, although the polychaetes could have some form of symbiosis.

\section{Demography of clam colonies}

The clam colonies examined here and those observed elsewhere during the Kaiko program (Sibuet et al. unpubl.) reveal several demographic features which have interesting ecological implications. Two points arise from the distinction of 4 separate species of Calyptogena among the specimens collected by the submersible: (1) The presence of 3 species of Calyptogena within the same cold seep field, and within the same colony, in Tenryu Canyon, implies resource partitioning and competition among 3 species with similar general habitat requirements. (2) The existence of a single, fourth species of Calyptogena at all the deeper sites points to possible depth limitations or other specific habitat requirements. This fourth species was only collected from 2 of the deeper sites, but it is readily distinguished from the other 3 species in photo and 
video records by its greater length and elongate form (Métivier et al. 1986).

A study of the digestive tracts of available specimens revealed that the 3 Tenryu Canyon species, in comparison to the species from the deeper sites, had better developed digestive tracts which contained greater quantities of ingested material (M. Le Pennec pers. comm.). This suggests that proportional contributions of filter feeding and chemosynthesis to meeting nutritional requirements may be one character differing among Calyptogena species and influencing their distribution.

Another notable demographic feature of the clam colonies is variation in the proportions of living and dead clams. Colonies consisting almost entirely of living or dead clams, and mixed colonies of living and dead clams, were seen throughout the region explored during the Kaiko program. Sampling has revealed that this aspect is not species specific. The presence of dead clams can firstly be attributed to natural senescence and mortality. In addition, assuming a vital dependence of the clams on porewater venting, the presence of groups of mainly dead clams indicates the site of a recently deteriorated cold seep: in some cases this may indicate a complete cessation of fluid flow. Predation does not appear to be an important cause of mortality, since it would presumably result in considerable dispersion of clams from the colonies and disarticulation of valves rather than the observed colony-like groups of articulated empty valves. We use the term 'recent deterioration' because the solubility of clam shells at depths of 3850 to $6000 \mathrm{~m}$, at or well below the carbonate compensation depth, would prevent their long-term preservation. The duration of dead Calyptogena shells at these depths is likely to be considerably shorter than the 15 to 25 yr estimated for their complete dissolution at $2500 \mathrm{~m}$ (Roux et al. 1983, Lutz et al. 1985). Signs of dissolutive weathering are even visible on shells of live-collected Calyptogena from the Kailko sites, in that portion of the shell which protruded from the sediment when the animal was in its living position.

Assuming that deterioration of fluid flow and natural mortality are the 2 main processes responsible for the presence of groups of articulated empty valves, 2 other deductions can be made regarding the duration of venting at a cold seep site. Living and dead clams within a single colony, such as at the Kashima site, would indicate that venting has continued long enough to allow the accumulation of empty valves by natural senescence, and perhaps mortality by crowdinginduced displacement away from fluid flow as has been suggested for Calyptogena at hydrothermal vents (Hessler et al. 1985). Groups dominated by or consisting entirely of living clams would mark more recently activated and colonised cold seep sites. Before the use of clam demography in dating cold seeps can be properly assessed, species longevity and rates of new site colonisation and shell dissolution will need to be better understood. Analysis of population structure (shell lengths) of living and dead clams within colonies and cold seep fields would be of great aid in understanding the history of colonisation and mortality. The proximity of new seep sites to a mother population of clams may be an important factor in determining the rate of colonisation, although the mechanism of larval dispersal for these Calyptogena species is unknown. C. magnifica, from hydrothermal vents, produces large yolk-filled eggs and likely has lecithotrophic larvae. It is not clear if these larvae develop within egg membranes or are demersal (Berg 1985). The locomotory activity of clams described by Ohta \& Laubier (1987) could permit limited colonisation of new sites within an active seep field, although this would be a very risky strategy where seeps were more than a few metres apart. Crowding or deterioration of fluid flow is one factor that could stimulate clams to move away from a seep site, but evidence of unsuccessful forays (i.e. isolated or scattered empty valves) was rare throughout the area explored during the Kaiko program. Our analyses of clam microdistribution and demography strongly suggest that the clams generally remain within the same closely-packed colony until death by senescence or deterioration of fluid flow.

\section{CONCLUSIONS}

\section{Spatial organization}

Calyptogena species are localised around the points of most intense fluid discharge. The fauna accompanying the clams, while not always constant in composition, displays distinct patterns of distribution. Suspension-feeding actinarians and serpulid polychaetes are attached to clam shells and nearby hard surfaces. Omnivorous and deposit-feeding species occur within and near the clam colonies. These include gastropods, galatheid crabs, caprellid amphipods and a large holothurian. The most abundant accompanying species are the tubiculous polychaetes and the swimming holothurians which occupy extensive areas of the sediment surface outside of the clam colonies.

\section{Trophic strategies}

At least 2 trophic levels are recognizable. The clams, with their apparent symbiosis, are obvious primary consumers, directly exploiting porewater fluids. A comparatively smaller biomass of secondary consumers 
likely exploits particulate organic matter produced by the clam colonies. This group includes serpulids, galatheids, actinarians, gastropods, caprellids, and possibly the large holothurian.

The large numbers of swimming holothurians and tubiculous polychaetes on sediments surrounding some clam colonies suggest the existence of a third major trophic pathway. We propose that there may be lowlevel porewater seepage outside of the clam colonies, which could enhance productivity by free-living chemosynthetic bacteria and locally enrich deposit feeder food resources.

\section{Temporal evolution}

Cold seeps appear to be ephemeral. The demographic features of Calyptogena colonies examined here - species composition, size, and proportion of living and dead clams - may prove to be useful indicators of environmental conditions and the recent history of venting activity at cold seep sites. The potential interest of this fauna/habitat relationship for the geophysical sciences, where the monitoring of cold seep activity has been proposed as a method for forecasting earthquakes (Boulègue et al. 1985), should encourage further study.

Acknowledgements. We are grateful to G. Pautot, X. Le Pichon, J.-P. Cadee and S. Lallemand for making photo and video documentation available and promoting this study through the Franco-Japanese cooperative Kaiko program. Comments by $\mathrm{V}$ Tunnicliffe and 3 anonymous reviewers were very helpful in improving an earlier version of this manuscript. This work also benefited from discussion with $M$. Le Pennec, $J$. Boulègue and $T$ Wolff. We also thank $V$. Martin for drafting of figures and G. Vincent for photographic plates. S. K. J. was supported by a post-doctoral fellowship from the French Ministry of External Relations.

\section{LITERATURE CITED}

Alperin, M. J., Reeburgh, W. S. (1985). Inhibition experiments on anaerobic methane oxidation. Appl. environ. Microbiol. 50: $940-945$

Berg, C. J., Jr. (1985). Reproductive strategies of molluscs from abyssal hydrothermal vent communities. In: Jones, M. C. (ed.) The hydrothermal vents of the Eastern Pacific; an overview. Biol. Soc. Wash. Bull. No. 6: 185-197

Boulègue, J., Benedetti, E. L., Drou, D., Mariotti, A., Letolle, R. (1987a). Geochemical and biogeochemical observations on the biological communities associated with fluid venting in Nankai trough and Japan trench subduction zones. Earth Planet. Sci. Lett. 83: 343-355

Boulègue, J., Iiyama, J. T., Charlou, J. L., Jedwab, J. (1987b). Nankai trough, Japan trench and Kuril trench: geochemistry of fluids sampled by Nautile submersible. Earth Planet. Sci. Lett. 83: 363-375

Boulègue, J., Le Pichon, X., Iiyama, J. T. (1985). Prévision des tremblements de terre dans la région de Tokai (Japon). C. r. hebd. Seanc. Acad. Sci., Paris, Série II, 16: 1217-1219

Burd, B., Brinkhurst, R. O. (1984). The distribution of the galatheid crab Munida quadraspina (Benedict 1902) in relation to oxygen concentration in British Columbia fjords. J. exp. mar. Biol. Ecol. 81: 1-20

Cadet, J. P., Kobayashi, K., Aubouin, J., Boulègue, J., Dubois, J., Von Huene, R., Jolivet, L., Kanazawa, T., Kasahara, J., Koizumi, K, Lallemand, S., Nakamura, Y., Pautot, G., Suyehiro, K., Tani, S., Tokuyama, H., Yamazaki, T. (1985). De la fosse du Japon à la fosse des Kouriles: premiers résultats de la campagne océanographique francojaponaise Kaiko (leg III). C. r. hebd. Séanc. Acad. Sc., Paris, Série II, 5: 287-296

Cavanaugh, C. M. (1983). Symbiotic chemoautotrophic bacteria in marine invertebrates from sulfide-rich habitats. Nature, Lond. 302: 58-61

Cavanaugh, C. M., Levering, P. R., Maki, J. S., Mitchell, R., Lidstrom, M. E. (1987). Symbiosis of methyltrophic bacteria and deep-sea mussels. Nature, Lond. 325: 346-348

Childress, J. J., Fisher, C. R., Brooks, J. M., Kennicutt, M. C., II, Bidigare, R., Anderson, A. E. (1986). A methanotrophic marine molluscan (Bivalvia, Mytilidae) symbiosis: mussels fueled by gas. Science 233: 1306-1308

Devol, A. H. (1983). Methane oxidation rates in the anaerobic sediments of Saanich Inlet. Limnol. Oceanogr. 28: 738-742

Felbeck, H., Childress, J. J., Somero, G. N. (1981). CalvinBenson cycle and sulfide oxidation enzymes in animals from sulfide-rich habitats. Nature, Lond. 293: 291-293

Fustec, A., Desbruyères, D., Juniper, S. K. (1987). Deep-sea hydrothermal vent communities at $13^{\circ} \mathrm{N}$ on the East Pacific rise: microdistribution and temporal variations. Biol. Oceanogr. 4: 121-164

Hecker, B. (1985). Fauna from a cold sulfur-seep in the Gulf of Mexico: comparison with hydrothermal vent communities and evolutionary implications. In: Jones, M. C. (ed.) The hydrothermal vents of the Eastern Pacific: overview. Biol. Soc. Wash. Bull. No. 6: 465-473

Hessler, R. R., Smithey, W. M., Jr., Keller, C. H. (1985). Spatial and temporal variation of giant clams, tube worms and mussels at deep-sea hydrothermal vents. In: Jones, $M$. C. (ed.) The hydrothermal vents of the Eastern Pacific: an overview. Biol. Soc. Wash. Bull. No. 6: 411-428

Juniper, S. K., Brinkhurst, R. O. (1986). Water-column dark $\mathrm{CO}_{2}$ fixation and bacterial-mat growth in intermittently anoxic Saanich Inlet, British Columbia. Mar. Ecol. Prog. Ser. 33: 41-50

Kennicutt, M. C., II, Brooks, J. M., Bidigare, R. 'R., Fay, R. R., Wade, T L., McDonald, T. J. (1985). Vent-type taxa in a hydrocarbon seep region on the Louisiana slope. Nature, Lond. 37: 351-353

Kulm, L. D., Suess, E., Moore, J. C., Carson, B., Lewis, B. T., Ritger, S. D., Kadko, D. C., Thornburg, T M., Embley, R. W., Rugh, W. D., Massoth, G. J., Langseth, M. G., Cochrane, G. R., Scamman, R. L. (1986). Oregon subduction zone: venting, fauna, and carbonates. Science 231 . $561-566$

Laubier, L., Ohta, S., Sibuet, M. (1986). Découverte de communautés animales profondes durant la campagne francojaponaise Kaiko de plongées dans les fosses de subduction autour du Japon. C. R. Acad. Sci., Paris, Série III, 2: 25-29

Le Pichon, X., Iiyama, T., Chamley, H., Charvet, J., Favre, M., Fujimoto, H., Furuta, T., Ida, Y., Kagami, H., Lallemant, S., Leggett, J., Murata, A., Okada, H., Rangin, C., Renard, V., Taira, A., Tokuyama, H. (1987). The eastern and western ends of Nankai trough: results of box 5 and box 7 Kaiko survey. Earth Planet. Sci. Lett. 83: 199-213 
Lutz, R. A., Fritz, L. W., Rhoads, D. C. (1985). Molluscan growth at deep-sea hydrothermal vents. In: Jones, M. C. (ed.) The hydrothermal vents of the Eastern Pacific: an overview. Biol. Soc. Wash. Bull. No. 6: 199-210

McCain, J. C. (1966). Abyssicaprella galatheae, a new genus and species of abyssal caprellid (Amphipoda: Caprellidae). In: Wolff, T. (ed.) Galathea report, Vol. 8. Danish Science Press, Copenhagen, p. 91-95

Métivier, B., Okutani, T., Ohta, S. (1986). Calyptogena (Ectenagena) phaseoliformis n. sp., an unusual vesicomyid bivalve collected by the submersible Nautile from abyssal depths of the Japan and Kurile Trenches. Venus 45: 75-86

Ohta, S., Laubier, L (1987). Deep biological communities in the subduction zone of Japan from bottom photographs during 'Nautile' dives in the Kaikko project. Earth Planet. Sci. Lett. 83: 329-342

Okutani, T., Metivier, B. (1986). Descriptions of three new species of vesicomyid bivalves collected by the submersible Nautile from abyssal depths of Honshu, Japan. Venus 45: $66-108$

Powell, E. N., Bright, T. J., Brooks, J. M. (1986). The effect of sulfide and an increased food supply on the melofauna and macrofauna at the East Flower Garden brine seep. Helgoländer Meeresunters. 40: 57-82

Rhoads, D. C., Lutz, R. A., Cerrato, R. M., Revelas, E. C. (1982). Growth and predation activity at deep-sea hydrothermal vents along the Galapagos Rift. J. mar. Res. 40: 503-516

Roux, M., Rio, M., Futton, E., Marien, G., Pachiaudi, C. (1983). Taux de croissance des grands Lamellibranches et reconstitution de l'activité hydrothermal à $21^{\circ} \mathrm{N}$ (dorsal due Pacifiquil oriental) enregistrée par coquille pendant environ 5 années. C. R. Acad. Sci., Paris, Série II, 297: 495-500

Rudd, J. W. M., Hamilton, R. D. (1975). Factors controlling rates of methane oxidation and the distribution of the methane oxidizers in a small stratified lake. Arch. Hydrobiol. 75: 522-538

Swinbanks, D. (1985a). Japan finds clams and trouble. Nature, Lond 315: 624

Swinbanks, D. (1985b). New find near Japan's coast. Nature, Lond. 31.6: 475

Whiticar, M. J., Faber, E. (1986). Methane oxidation in sediment and water column environments - isotope evidence. Org. Geochem. 10: 759-768

This article was submitted to the editor; it was accepted for printing on July 10,1987 